\author{
Martina RYSULOVA ${ }^{1}$ \\ Daniela KAPOSZTASOVA ${ }^{2}$ \\ Zuzana VRANAYOVA ${ }^{3}$
}

\title{
SAFETY MANAGEMENT OF GREY WATER - PREVENTION AGAINST POTENTIAL SYSTEM RISKS
}

\begin{abstract}
Using recycled water or grey water system is relatively new concept in Slovakia, which gives users or investors an impression, that something what is new and unproven, may not be reliable. It is obvious, that in some cases, there may arise the situation, which wasn't expected and system can fail, despite taking all necessary measures, however this can occur even in systems used safety for years. This report focuses on grey water system application and determines its potential risks, which can bring benefits, especially in terms of prevention of their creation. Then we know to which parts of the system, we have to give special attention, whether in the designing process, using or maintenance and we can ensure efficient and reliable system. This report deals with the potential risks of grey water system and the way how to avoid them, while it is important to remember that naming of the risks are just theoretical, and it doesn't mean that they will occur.
\end{abstract}

Keywords: potential risks, control measures, systems parts, risks factors

\section{Introduction}

It goes without saying, that in systems designing part and during its utilization, we want to ensure safety and functional system. One of the possibilities, how to arrange it, could be naming the potential systems risks, which can occur during the system utilization. Then suggest control measures of this risks, as tool, how to avoid their creation, and system can become more safety and functional.

${ }^{1}$ Author for correspondence: Martina Rysulova, PhD student, Vysokoskolska 4, 04200 Košice, Slovakia,00421908075057,martina.rysulova@tuke.sk.

2 Daniela Kaposztasova, Vice Dean for Education, Vysokoskolska 4, 04200 Košice, Slovakia, daniela.kaposztasova@tuke.sk.

${ }^{3}$ Zuzana Vranayova, Vice Chairman of Academic Senate, Vysokoskolska 4, 04200 Košice, Slovakia, zuzana.vranayova@tuke.sk. 
Focus of this article is on the potential risks and control measurements of grey water system. This system is reusing waste water from sanitary appliances as sinks, kitchen sinks, baths, showers or washing machines, also known as grey water, again in building water cycle. There are several ways for utilization of this water. After required treatment, when is this water called white water, are most common ways of end use toilets and urinals flushing, cleaning, irrigation or washing machines.

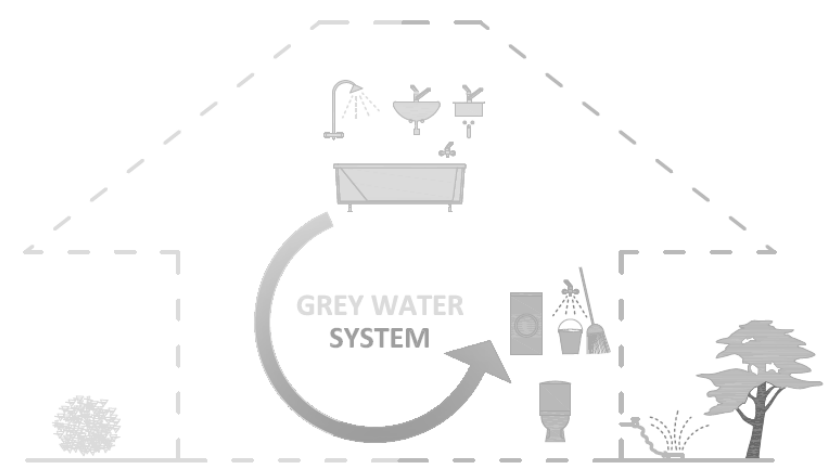

Fig. 1. Schema of grey water system reuse

Rys. 1. Schemat systemu ponownego użycia wody gospodarczej

\section{Control measures against potential risks}

Before determination of control measures, is important to establish the potential risks of the system. According to this requirement, the system can be divided into four basic parts:

- collection

- accumulation

- distribution

- using

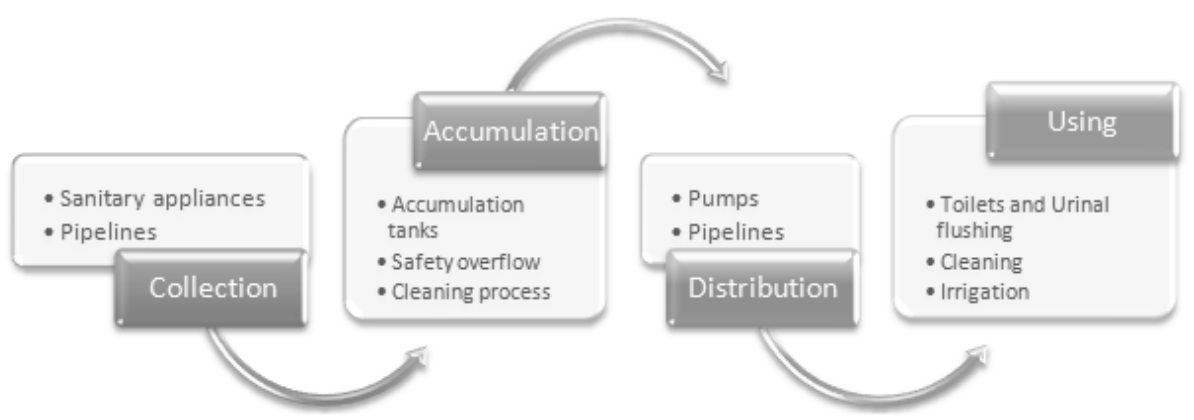

Fig. 2. Schema of the four basic grey water system parts

Rys. 2. Schemat czterech podstawowych części systemu wody gospodarczej 


\subsection{Collection part}

Potential risks in this systems part, are mainly sanitary appliances, from which we are collecting the grey water. Certain possibility of defect can represents also the pipelines, which transports the grey water from their creation part into the wastewater treatment tank and accumulation tanks.

\subsubsection{Potential risks}

Sanitary appliances is the most risky part of the system, particularly because of the unpredictable quality of discharged water. This quality is directly depended on the users behavior. From sinks may be consciously or unconsciously discharged the dangerous substances, which may have impact on water quality or users health. The situation, when the grey water from showers or baths contains indicators of fecal contamination, which means microbiological contamination of water can occur commonly. As a result of this contamination is again dangerous impact on users health. Discharging the dangerous substances can be expected from kitchen sinks. This water may contain solid particles, such as food scraps, fats and oils, which may cause deposition of impurities in the pipeline and infract the pipelines, activities or clog the pipes.

The potential risks of the pipelines, are depended on the discharged water properties. In case that discharged water contains solid particles, the water flow may be disturbed and the pipes can get stuck, water may be stagnating, and spread odors, what may impact the users comfort.

\subsubsection{Control measures}

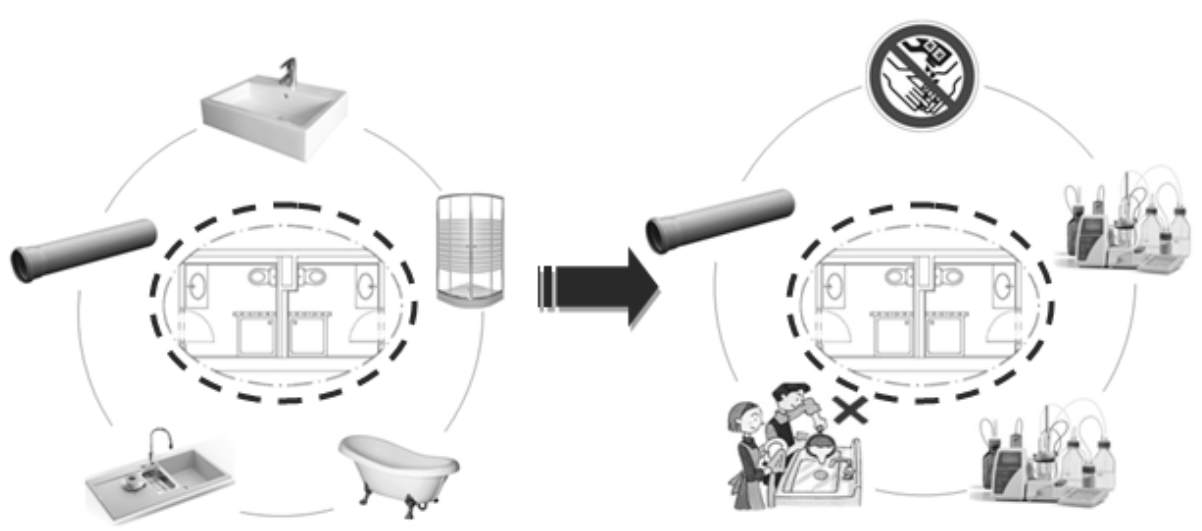

Fig. 3. Schema of systems potential risks and control measures in collection system part

Rys. 3. Schemat systemu potencjalnego ryzyka i środków kontroli w odzyskującej części systemu 
Important control measure in this system part is to ensure the discharging of waste water which does not contain the dangerous substances. This requirement is directly dependent on the user and access to utilization of this system. Risk of microbiological contamination of water from baths and showers is difficult to solve, according to fact, that the fecal polution substances, may be discharged into the sewerage unconsciously. But with regular controls of water quality, and its condition will be easier to establish or during system utilization modify sufficient water treatment.

Correct selection of the pipelines material and their regular maintenance, can prevent the formation of all their potential risks.

\subsection{Accumulation part}

In this systems part, are all of the risks, associated with wastewater treatment plant. and we can divide it into 3 basic parts: accumulation tanks, safety overflow and cleaning process.

\subsubsection{Potential risks}

The primary risk of the accumulation tanks, may arise already in their designing process. Accumulations tanks could be overdesigned or undersizing. More often situation is overdesigning the system. The reason why is usually system overdesigned is that water demand and daily production of grey water is usually designed on systems load maximum, which is very rare situation. In case that the size of water tank is not sufficient, it is necessary to ensure discharging the water by safety overflow. Excess of water in tank may cause its damage and leakage of water from tank. Therefore it is important, that all tanks have to be fixed and resistant to insects and rodents, because they occurrence in water can dangerously contaminated the water quality.

In case that accumulation tank is provided with safety overflow, but wrongly, as results can occur the several risks. The tank can get broken, which can lead to waters leakage flooding and property damage. The safety overflow, can also serve as a way for rodents or insects into the tank, which presence in thank may have dangerous impact on water quality.

The cleaning process is the most important part of the whole grey water system, because water couldn't be returned back into building without a proper cleaning process. Therefore the risks may arises already in designing process, by choosing an inadequate treatment, what can impact users health. The pump can also means the certain risk, because if we choose the wrong type, with insufficient power, the entire system may failed. Incorrect or missing maintenance of the pump, may restrict or completely stop the systems operation. 


\subsubsection{Control measures}
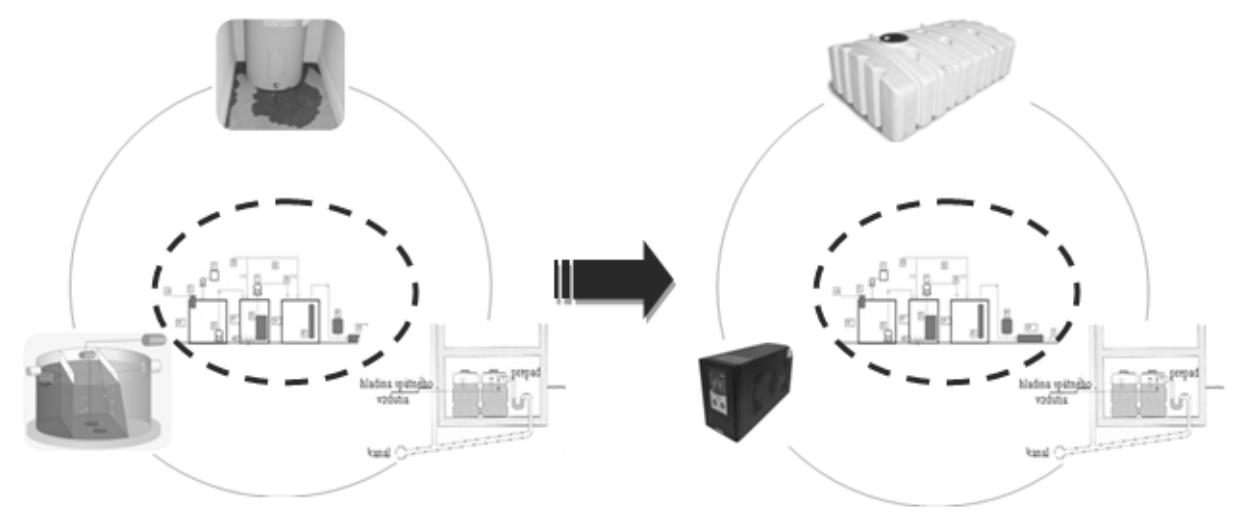

Fig. 4. Schema of systems potential risks and control measures in accumulation system part

Rys. 4. Schemat systemu potencjalnego ryzyka i środków kontroli w gromadzącej części systemu

The first control measure in accumulation system part is focused on designing the accumulation tanks, their capacity and proper construction. During the designing part of the accumulation tanks, we have to avoid the situation of undersizing their capacity. According to common calculations for dimensioning the tanks, there is a low probability that tanks will be undersized, since the tanks capacity is designed for the systems load maximum. Also the design and execution of the tanks have to be realized responsibly, focusing on the critical points on tanks construction as entry and exit of the pipelines, overflow and secure these part.

Certainly is important to provide the overflow from the tanks, mainly to ensure the tanks in front of situation of high grey water production and tank capacity will not be able to cover this production. If the water will reach the maximum allowed amount in tank, the overflow ensure the simply water runoff of to the sewer system.

For ensure the appropriate cleaning process is important to set the regular monitoring of water quality and in case of changing quality of water, apply the additional cleaning methods. Also important is regular maintenance and monitoring of equipment condition.

\subsection{Distribution part}

In the distribution systems part, there are also places of potential risks. Mainly they are pumps and pipelines. 


\subsubsection{Potential risks}

The pumps can also represent some risk factor, because if we choose the wrong type, which power will not enough, the entire system may failed. Incorrect or missing maintenance of the pump may restrict or completely stop systems operation.

The pipelines distributing the white water back to building, are the important elements of grey water system. They serve as a connection with wastewater treatment and the final systems application. However in this part we may also expect some potential risks. The most critical is the connection of white water and potable water, which could have dangerous impact at users. In the case of insufficiently pipelines coupling during installation or its distortion during using, may occur situations of water leakage which can disturb the place, where the pipes is held or reduce systems efficiency at all.

\subsubsection{Control measures}

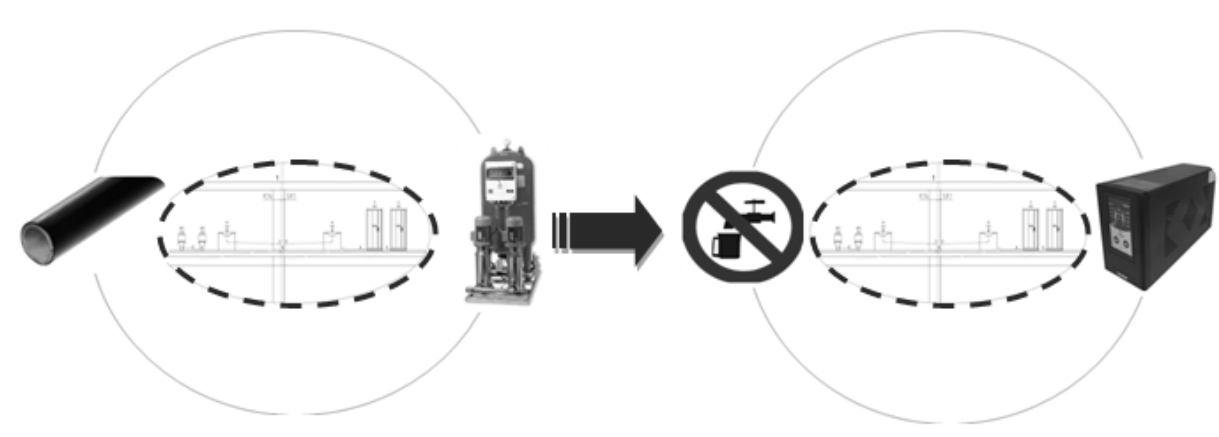

Fig. 5. Schema of systems potential risks and control measures in distribution system part

Rys. 5. Schemat systemu potencjalnego ryzyka i środków kontroli w rozdzielającej części systemu

For the pumps is suitale to provide appropriate backup power, which procures the power for pump in case of power failure and keeps the system still running and functional.

During the installation process, we can prevent all potential risks of pipelines. The each pipeline have to be marked and we have to prevent their conection. Necessary measure is to realize shut-off valves on pipelines, which ensure the simplier maintenance of the pipelines. In this regard it is necessary to choose reliable and qualified team of professionals, who can take care of proper installation of the pipelines. 


\subsection{Using part}

For this initial part of the system is the most important indicator, the impact on the users health. According to that it is important to identify all the systems potential risks that may occur and prevent their creation.

\subsubsection{Potential risks}

Type of risk contained in this systems part is also as the input part of the system directly dependent on the users behavior. When using grey water for toilets flushing, as a risk we can consider the water quality, because water is secondary accumulated on the toilet bowls, so its quality is during accumulation still changing. Another assumption of the risks is that the users will not closing the toilets lid. Then it is a huge possibility of inhalation the microorganisms and various pollutants during the flushing. Risky are also the typological solutions of the bathrooms, which includes toilets, then is the inhalation more possible. Not so serious, but also important impact, can have the deposition of impurities in the toilets and urinals, which leads to odors dissemination and make the users feel uncomfortable.

When using white water is also important the quality of the water. If white water contains dangerous substances, or it was contaminated, and these water will be used for cleaning, we can extend this bad quality water trough the building, and in contact with users may impact their health.

If water contains dangerous substances such as boron, whose incidence can result in toxic effects to plants, microorganisms or different dangerous substances and we use it for irrigation, it may have dangerous effect on the surrounding environment.

\subsubsection{Control measures}
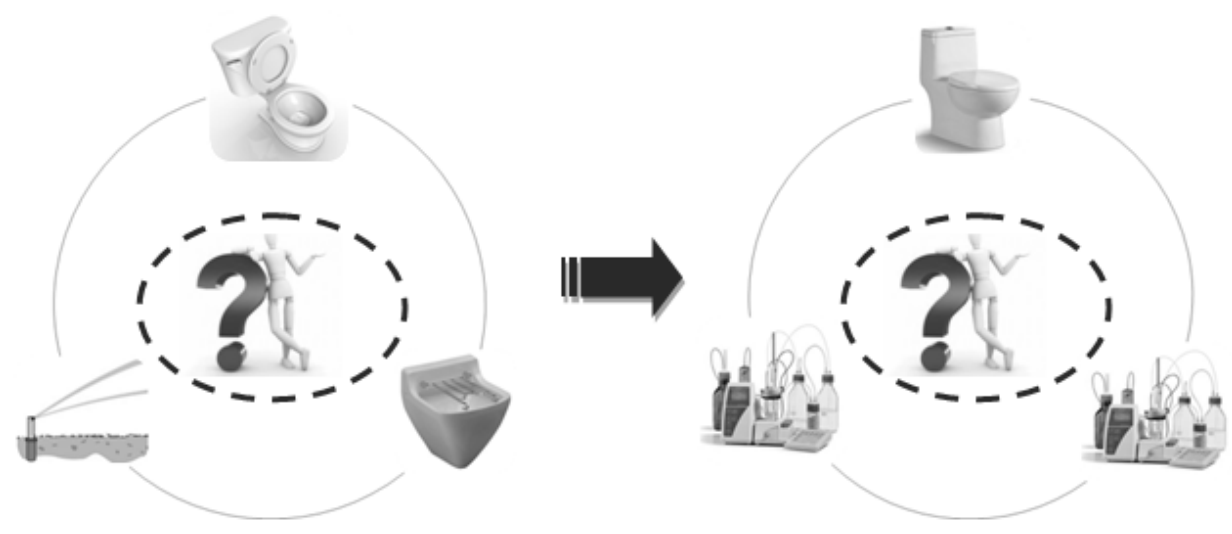

Fig. 6. Schema of systems potential risks and control measures in using system part

Rys. 6. Schemat systemu potencjalnego ryzyka i środków kontroli w użytkowej części systemu 
To reduce the risk associated with inhalation of microorganisms and dangerous substances, it is necessary to inform users about the importance of closing the toilets lid, particularly in the united bathrooms and toilets.

White water, which will serve as a source for cleaning and irrigation must be wholesome, what can be ensured by regular controls of water quality.

\section{Conclusion}

Naming the potential risks of grey water system, can serve as a tool, with which we can enhance the system and make it more safety and functional. It is obvious, that in some cases, there may arise the situation, which wasn't expected and system can fail, despite taking all necessary control measures, however this can occur even in systems used safety for years. This report focuses on grey water system application and determines its potential risks, which can bring benefits, especially in terms of prevention of their creation. Then we know to which parts of the system we have to give special attention, whether in the designing process, using or maintenance and we can ensure efficient and reliable system. This report deals with the potential risks of grey water system and the way how to avoid them, while it is important to remember, that naming of the risks are just theoretical, and it doesn't mean that they will occur.

\section{Aknowledgement}

This work was supported by projects VEGA n. 1/0202/15: Sustainable and Safe Water Management in Buildings of the $3{ }^{\text {rd }}$ Millennium.

This work was supported by The APVV - SK-CZ-2013-0188 Lets Talk about the Water - An Essential Dimension of Sustainable Society of the 21. Century.

\section{Bibliography}

[1] Afonso S., et cal. Grey water in buildings. The Portuguese approach. IN: Proceedings of 37th International Symposium CIB W062 on Water Supply and Drainage for Buildings, Aveiro 2011, ISBN: 978-989-97476-0-9

[2] BS 8525-1:2010 Greywater systems PArt 1: Code of practise. UK: BSI,2010

[3] Chen Z, Ngo HH, GuoW. A critical review on the end uses of recycled water. Crit Rev Environ Sci Technol 2013;43:1446-516.

[4] March J.G., Gual M., Orozco F., Experiences on greywater re-use for toilet flushing in a hotel (Mallorca Island, Spain). [onine].[cit.2015-03-03]. Available on the internet: http://www.sciencedirect.com/science/article/pii/S0011916404001924

[5] Markovič, G. Využitie zrážkovej vody z povrchového odtoku v budovách. 2010. Juniorstav 2010: 12. odborná konference doktorského studia: sborník anotací. Brno. 24.2.2010. VUT Brno. 2010. s. 1-7. ISBN: 978-80-214-4042-5.

[6] Markovič G., Zeleňáková M., Measurements of quality and quantity of rainwater runoff from roof in experimental conditions - 2014. In: ICITSEM 2014 : International conference on innovative trends in science, engineering and managment 2014: 
12th and 13th February 2014, Dubaj, UAE. - [Bangalore]: Mudranik Technologies, 2014 P. 145-151. - ISBN 978-93-83303-19-9

[7] Ottoson J, Stenstrom TA. Faecal contamination of greywater and associated microbial risks. Water Res 2003;37:645-55

[8] O'Toole J, Sinclair M, Malawaraarachchi M, Hamilton A, Barker SF, Leder K.: Microbial quality assessment of household greywater. Water Res 2012;46:4301-13.

[9] Raclavska, H.et al:Municipal Waste Water Toxicity Evaluation with Vibrio Fisheri, Recent advances in environment, energy, ecosystems and development (EEEAD 2013), p.226, September 28-30, 2013, Venice, Italy

\section{ZARZADZANIE BEZPIECZEŃSTWEM WODY GOSPODARCZEJ - ZAPOBIEGANIE POTENCJALNYM RYZYKOM SYSTEMOWYM}

\section{Streszczenie}

Używanie odzyskanej wody albo systemu wody gospodarczej jest stosunkowo nowym pojęciem na Słowacji, który daje użytkownikom albo inwestorom wrażenie, że to co jest nowością i nie jest sprawdzone, nie może być niezawodne. Jest oczywistym, że w niektórych przypadkach, może wystąpić nieoczekiwana sytuacja i system może być zawodny, pomimo użycia wszystkich koniecznych środków. Jednak może to wystąpić nawet w systemach bezpiecznie użytkowanych przez wiele lat. Artykuł przybliża zagadnienia dotyczące systemów wykorzystania wody gospodarczej i ustala potencjalne ryzyko, któremu zapobieganie może przynosić wymierne korzyści. Jeżeli jest znane na którą części systemu, należy zwrócić szczególną uwagę podczas procesu projektowania, użytkowania albo utrzymania można zapewniać skuteczny i niezawodny system. Artykuł podaje potencjalne ryzyko występujące w systemie wody gospodarczej i sposoby jak ich unikać pamiętając, że zjawiska nazywane ryzykiem są po prostu teoretyczne, i nie oznacza, że muszą nastąpić.

Słowa kluczowe: potencjalne ryzyko, środki kontroli, części systemu, czynnik ryzyka

Przestano do redakcji:5.05.2015

Przyjęto do druku:1.12.2015

DOI: $10.7862 / \mathrm{rb} .2015 .163$ 